\title{
Kajian Hukum Adat Dari Perspektif Sosiologi Hukum
}

\author{
Joejoen Tjahjani \\ joejoen668@gmail.com
}

Fakultas Hukum Universitas Islam Lamongan

\begin{abstract}
ABSTRAK
Hukum adat adalah suatu system hukum karena hukum adat memenuhi kriteria dan merupakan bagian dari hukum secara keseluruhan, yang sumbernya adalah peraturanperaturan yang tidak tertulis yang tumbuh dan berkembang dan dipertahankan dengan kesadaran hukum masyarakatnya. Dengan metode yuridis normative memberikan gambaran selengkap-lengkapnya mengenai norma hukum adat dari perspektif sosiologi hukum. Kajian terhadap hukum adat dari perspektif sosiologi hukum merupakan bagian dari proses terjadinya hukum dan fungsi hukum terutama sebagai pengendalian social menuju pada kepastian dan penegakkan hukumnya. Dalam hukum adat justru mengatur delik yang dianggap berat yang tidak diatur dalam KUHPidana, sehingga dapat dipertahankan hukum asli bangsa Indonesia.
\end{abstract}

Kata kunci : Hukum, Adat Istiadat, Sosiologi Hukum

\section{PENDAHULUAN}

Berawal dari semangat mahasiswa dalam mengikuti materi kuliah hukum adat terbersit keingintahuan mereka terhadap hukum adat. Bagaimana adat bisa menjadi suatu hukum nasional sedangkan adat merupakan kebiasaan yang tidak tertulis begitu pula dengan sanksinya. Sedangkan Indonesia yang merupakan negara hukum sudah menerapkan hukum berdasarkan undang-undang yang tertuang dalam hukum positif.

Adat dipandang sebagai suatu tradisi/kebiasaan sehingga terkesan sangat lokal, ketinggalan jaman, kadang bertentangan dengan ajaran agama dan lainlain. Hal ini dapat dimaklumi karena "adat" adalah suatu aturan tanpa adanya sanksi riil (hukuman) di masyarakat kecuali menyangkut soal dosa adat yang berkaitan dengan soal-soal pantangan/tabu untuk dilakukan. Adat bisa juga diistilahkan tradisi, kebiasaan dan adat istiadat.

Hukum adat yang merupakan sistem hukum tidak hanya dikenal dalam lingkungan kehidupan sosial di Indonesia tetapi juga terdapat di negara-negara lainnya seperti India, Tiongkok dan Jepang. Hukum adat Indonesia adalah hukum asli bangsa Indonesia yang sumbernya digali dari peraturanperaturan hukum tidak tertulis yang tumbuh dan berkembang dan dipertahankan dengan kesadaran hukum masyarakatnya. Karena itu maka hukum adat memiliki kemampuan 
menyesuaikan diri dan elastis. Berkaitan dengan hukum adat dikenal pula masyarakat hukum adat yaitu sekelompok orang yang terikat oleh tatanan hukum adatnya sebagai warga bersama suatu persekutuan hukum karena kesamaan tempat tinggal ataupun atas dasar keturunan. Dari perspektif sosiologi hukum hal tersebut merupakan bagian dari proses terjadinya hukum dan fungsi hukum terutama sebagai pengendalian social. Contoh beberapa hukum adat di Indonesia :

1. Hukum Adat di Lampung;

2. Hukum Adat di Minangkabau;

3. Potong jari di Papua;

4. Berjenjang di Aceh;

5. Desa adat dengan segala ketentuannya termasuk warisan, subak di Bali dan sebagainya

Tidak semua adat dapat dijadikan sumber hukum adat meskipun sebagai pengendalian social tapi juga harus memperhatikan kemanusiaan. Contohnya : penghapusan diberlakukannya hukum adat masyarakat suku Naulu Maluku yang masih menganut pemberian mahar pernikahan berupa kepala manusia yang dipenggal. Meskipun masyarakat setempat percaya bahwa hal itu akan membawa kelanggengan bagi rumah tangga mereka nantinya, tetapi hal ini tidak sesuai dengan konsep hak asasi manusia yang merupakan salah satu unsur Negara hukum.
Beberapa corak hukum adat adalah :

1. Tradisional;

2. Keagamaan/kepercayaan;

3. Kebersamaan (bercorak komunal);

4. Konkrit dan visual;

5. Terbuka dan sederhana;

6. Dapat berubah dan menyesuaikan;

7. Tidak dikodifikasi;

8. Musyawarah dan mufakat.

Perkembangan dan corak hukum adat sangat ditentukan oleh perilaku adat yang membentuknya.

Keberadaan hukum adat dalam system hukum nasional Indonesia mendapat tempat penting dan strategis. Hukum adat sebagai bagian dari hukum yang hidup dan berkembang dalam masyarakat sudah ada jauh sebelum produk hukum kolonial diberlakukan di Indonesia atau bahkan pada sejarah kolonialisme di Indonesia.

Eksistensi hukum adat dalam hukum nasional Indonesia dipengaruhi oleh berlakunya system hukum adat itu sendiri yang mampu menegakkan fungsi hukum sebagai sarana pengendalian social atau social control.

\section{METODE}

Jenis penelitian yang digunakan adalah yuridis normative, yaitu untuk memberikan gambaran selengkaplengkapnya mengenai norma hukum adat dari perspektif sosiologi hukum. Metode 
yang diterapkan adalah yuridis empiris, karena dari segi yuridis penelitian ini mengkaji peraturan hukum adat yang dijadikan landasan dalam penyelesaian masalah hukum yang berpijak pada adat. Sedangkan dari segi empiris mengkaji permasalahan yang timbul karena perbuatan yang dianggap melanggar hukum adat yang sebagian besar merupakan hukum tidak terulis yang digali dari kebiasaan yang berlaku di masyarakat.

\section{PEMBAHASAN}

Dari perspektif sosiologi hukum ada dua hal yang dapat dikaji dari hukum adat. Yaitu dari proses terjadinya hukum adat dan fungsi hukumnya.

Bagaimana perilaku bisa menjadi hukum adat?

Proses interaksi atau hubungan interpersonal yang terus-menerus menimbulkan pola-pola tertentu yang disebut 'cara' (usage). Dalam perkembangannya cara-cara yang diterapkan untuk penyelesaian masalah di suatu masyarakat/desa adat bisa menimbulkan suatu 'kebiasaan' atau folkways. Kebiasaan yang diakui atau diterima sebagai kaidah menjadi 'tata kelakuan' atau mores. Tata kelakuan yang kekal serta kuat dengan perilaku

\footnotetext{
${ }^{1}$ Soerjono Soekanto, Hukum Adat Indonesia,
}

masyarakat/desa adat kekuatan mengikatnya akan meningkat menjadi 'adat istiadat' atau custom.

Menurut Soekanto dan Soerjono Soekanto (1979:15) :

“....suatu kepastian hukum akan dapat dihasilkan oleh kaidah-kaidah yang mempunyai kekuatan mengikat yang lebih kuat, yang mengatur tata kehidupan masa kini dan masa-masa mendatang. Kecuali daripada itu, maka juga diperlukan kaidah-kaidah yang dengan tegas menetapkan hak-hak dan kewajiban-kewajiban warga-warga masyarakat yang apabila mungkin diperkuat dengan sanksi-sanksi apabila kaidah tersebut dilanggar."1

Apabila terdapat sanksi yang diterapkan dalam suatu adat istiadat maka custom akan meningkat menjadi suatu 'hukum adat', karena dalam hukum adat juga berisikan perintah, larangan dan kebolehan.

Untuk mempertegas bahwa hukum adat merupakan suatu system hukum yang dibentuk berdasarkan sifat, pandangan hidup dan cara berfikir masyarakat Indonesia kemudian Soepomo membandingkan system hukum adat dengan system hukum barat. Nampak bahwa hukum adat memiliki system hukum yang sangat sederhana

PT. Raja Grafindo Persada, Jakarta.h.74 
dibandingkan dengan system hukum barat. Misalnya uraian tentang hukum didalam kitab hukum adat Lampung yang disebut "Kuntara Raja Niti" yang tidak sistematik, oleh karena tidak dikelompokannya kaidah-kaidah hukum yang sama, uraian pasal-pasalnya melompat-lompat. Sedangkan jika dilihat hukum barat telah memiliki istilah-istilah hukum teknis yang dibina berabad-abad oleh para ahli hukum, para hakim, dan oleh pembentuk UU. Oleh karena itu R. Soepomo mengatakan bahwa bagi hukum adat, pembinaan bahasa hukum adalah soal yang meminta perhatian khusus kepada ahli hukum di Indonesia. $^{2}$

Karena merupakan system hukum maka hukum adat tidak lepas dari pespektif sosiologi hukum terutama sebagai fungsi pengendalian social atau social control.

Menurut Prof. Koentjaraningrat, terdapat lima macam fungsi social control, yaitu :

a. Mempertebal keyakinan masyarakat tentang kebaikan norma.

b. Memberikan imbalan kepada warga yang menaati norma.

c. Mengembangkan rasa malu.

d. Mengembangkan rasa takut.

e. Menciptakan sistem hukum. ${ }^{3}$

\footnotetext{
${ }^{2}$ Prof. Dr. C. Dewi Wulansari, SH, MH, SE, MM., Hukum Adat Indonesia Suatu Pengantar, Refika Aditama, Bandung.h.23
}

Berikut ini adalah cara-cara yang dapat dilakukan dalam pengendalian sosial masyarakat, yaitu :

a. Pengendalian Sosial Persuasif. Merupakan pengendalian lisan yang diberikan dengan menggunakan bahasa lisan guna mengajak anggota kelompok social masyarakat untuk mengikuti peraturan yang berlaku.

b. Pengendalian Simbolik. Merupakan pengendalian simbolik yang dilakukan melalui gambar, tulisan, iklan, dan lain-lain. Contoh : Spanduk, poster, rambu Lalu Lintas.

c. Pengendalian Koersif. Merupakan pengendalian melalui cara kekerasan yaitu suatu tindakan yang dilakukan untuk membuat si pelanggar jera sehingga tidak berani melakukan kesalahan yang sama. Contohnya seperti main hakim sendiri.

Sistem social control mengandung unsur unsur seperti mengatur, memaksakan dan bahkan dipatuhi oleh mayarakat. Nilai nilai itulah yang dikenal dalam hukum adat sebagai pengendali sosial yang diyakini sangat kuat menjaga kestabilan dan

\footnotetext{
${ }^{3}$ Soerjono Soekanto, Hukum Adat Indonesia, PT. Raja Grafindo Persada, Jakarta.2016, h.80
} 
keserasian pada setiap perubahan yang terjadi.

Aspek normatif terlihat jelas dalam sistem social control masyarakat yang secara sosiologis tidak dapat disamakan antara daerah yang satu dengan daerah yang lain. Dapat ditemukan juga di suatu kelompok tertentu keluarga dalam satu rumah, lembaga pemasyarakatan yang menjadi pedoman mengenai apa yang benar dan apa yang salah termasuk etika, adat istiadat, birokrasi dan sebagainya; dalam suatu komunitas masyarakat. Pengendalian sosial yang sifatnya informal lebih tampak efektif misalnya dengan sanksi pengasingan dari pergaulan.

Mengenai perkembangan peranan penguasa masyarakat hukum adat dapat dicontohkan system kepemimpinan di Minangkabau yang didasarkan pada system tiga-tungku sejarangan (Herman Sihombing 1981:5) yaitu :

a. Pimpinan, Kepemimpinan : Ninikmamak-pemangku adat;

b. Pimpinan, Kepemimpinan : AlimUlama;

c. Pimpinan, Kepemimpinan : Cerdik pandai;

Dari susunan di atas dapat diketahui dari kepemimpinan yang diatas mula-mula hanya masalah/bidang adat saja (Ninikmamak-pemangku adat) kemudian dengan masuknya agama (terutama Islam) maka timbul unsur pemimpin agama, dan factor agama turut menentukan kehidupan dalam masyarakat (Alim-Ulama) maka bersama ninik-mamak adat memimpin kesatuankesatuan social masyarakat dalam adat. Dengan kemajuan yang dihasilkan oleh system pendidikan dan perekonomian timbul unsur pimpinan baru (Cerdikpandai) yang pendapatnya, perkataannya juga menentukan dalam masyarakat sehingga cerdik-pandai juga disertakan dalam kepemimpinan masyarakat adat (nagari). Dengan demikian gejala social yang menimbulkan perubahan social di masyarakat adat Minangkabau harus dapat decontrol/dikendalikan oleh ketiga-tungku sejarangan di atas sesuai hukum adat yang berlaku.

Eksistensi hukum adat dan masyarakat adat dalam persaingan global, menunjukkan bahwa hukum adat sebagai bagian hukum yang hidup haruslah ada dan hidup secara berdampingan dengan hukum nasional yang berlaku.

Dalam UUD Tahun 1945 Perubahan Kedua pasal 18 B ayat (2) telah ditentukan bahwa negara mengakui dan menghormati kesatuan-kesatuan masyarakat hukum adat beserta hak-hak tradisionalnya sepanjang masih hidup dan sesuai dengan perkembangan masyarakat dan prinsip Negara kesatuan Republik Indonesia yang diatur dalam undang-undang. 
Dalam UU No. 6 Tahun 2014 tentang Desa disebutkan wewenang Desa Adat untuk menyelesaikan permasalahan hukum warganya diakui oleh Negara melalui pasal 103 huruf d dan e yang menyatakan bahwa penyelesaian sengketa adat berdasarkan pada hukum adat yang berlaku di desa adat dalam wilayah yang selaras dengan prinsip hak asasi manusia secara musyawarah; juga penyelenggaraan sidang perdamaian peradilan desa adat sesuai dengan ketentuan peraturan perundang-undangan.

Dalam UU No. 48 Tahun 2009 tentang kekuasaan kehakiman pasal 5 (1) dinyatakan bahwa hakim dan hakim konstitusi wajib menggali, mengikuti dan memahami nilai-nilai hukum dan rasa keadilan yang hidup dalam masyarakat. Hal ini dimaksudkan agar putusan hakim dan hakim konstitusi sesuai dengan hukum dan rasa keadilan masyarakat. Putusan pengadilan selain harus memuat alasan dan dasar putusan juga memuat pasal tertentu dari peraturan perundang-undangan yang bersangkutan atau sumber hukum tak tertulis yang dijadikan dasar hukum untuk mengadili. Meskipun secara structural pengadilan adat tidak terikat dalam hubungan hirarkis dengan badan-badan peradilan formal di Indonesia tetapi posisi peradilan adat dapat dipersamakan sebagai salah satu bentuk lembaga alternative penyelesaian sengketa yang diatur dalam
UU No. 30 Tahun 1999 tentang Arbitrase dan Alternatif Penyelesaian Sengketa.

Dalam ranah pidana terdapat yurisprudensi yang juga mengakui pidana adat sebagai sumber hukum contoh putusan Pengadilan Tinggi Makassar No. 427/Pid/2008.

Hukum adat bisa dikatakan masih hidup apabila dapat diukur kekuatan materilnya.

Ukuran ini menjadi bahan pertimbangan para hakim dalam memberikan suatu putusan (jurisprudensi) apakah hukum adat itu sudah berubah, berkembang atau masih tetap seperti hukum adat asli yang digambarkan di dalam literatur (doktrin) lama. Ukuran ini juga sangat berperan dalam memudar dan berkembangnya hukum adat, karena penelitian terhadap setiap perkembangan hukum adat sebagai hukum yang hidup perlu dijadikan pedoman dalam menyelesaikan kasus-kasus sengketa di pengadilan.

Mengenai peran hukum adat dalam pembangunan, Soerjono Soekanto menyatakan bahwa konteks social dari masing-masing suku bangsa akan memberikan warna tertentu pada hukum adat. Namun tidak mustahil bahwa dari perbedaan yang ada dapat dicari persamaan dalam asas hukumnya. Oleh karena itu dalam mengadakan identifikasi terhadap 
hukum adat yang mungkin berperan di dalam pembangunan, maka perlu diadakan kegiatan-kegiatan ilmiah untuk menentukan hal-hal sebagai berikut:

1. Identifikasi terhadap hukum adat yang menunjang pembangunan, hukum adat mana yang diperkuat;

2. Hukum adat yang bersifat netral dalam pembangunan;

3. Hukum adat yang bertentangan dengan pembangunan, dengan kemungkinan-kemungkinan sebagai berikut :

a. Hukum adat yang secara tegas bertentangan dengan pembangunan

b. Hukum adat yang bertentangan dengan pembangunan, akan tetapi yang dengan sendirinya terhapus di dalam proses pembangunan $^{4}$

c. Hukum adat yang bertentangan dengan pembangunan, tetapi yang terbukti tidak relevan lagi.

Disamping hal-hal tersebut diatas maka perlu diidentifikasikan hal-hal sebagai berikut :

1. Hukum adat yang dianut karena diperintahkan oleh penguasa adat, yang belum tentu dirasakan adil,
2. Hukum adat yang dianut karena kolektivitas menghendakinya, padahal belum tentu adil,

3. Hukum adat yang dianut oleh karena dianggap adil oleh warga masyarakat secara individual.

Hukum tertulis yang tidak didasarkan pada hukum adat yang telah mengalami saringan, tidak akan mempunyai basis yang kuat. Artinya hukum tertulis tersebut goyah dan nantinya menjadi hukum yang mati karena tidak efektif. Tidak efektifnya hukum tertulis akan mengakibatkan merosotnya wibawa hukum, termasuk wibawa para penegaknya. ${ }^{5}$

\section{IV.PENUTUP}

Dalam pembahasan diatas tampak jelas dari perspektif sosiologi hukum bahwa pengembangan hukum adat nasional bersumber dan harus digali dari nilai-nilai hukum yang hidup dalam masyarakat (the living law), agar hukum nasional di masa yang akan datang mampu mencerminkan nilainilai sosial, budaya dan susunan masyarakat Indonesia. Sehingga dapat dipertahankan hukum asli bangsa Indonesia seperti adanya Desa Adat dan subak di Bali, pola kepemimpinan adat di Minangkabau dan sebagainya. 
Beberapa aturan perundang-undangan secara normatif telah mengamanatkan adanya pengakuan dan perlindungan untuk masyarakat Hukum Adat, meskipun implementasinya belum sesuai yang diharapkan.

Dalam hal terjadinya suatu pelanggaran dalam masyarakat seharusnya tidak langsung diselesaikan dengan hukum positif (hukum Negara) namun lebih baik diselesaikan terlebih dahulu secara hukum adat misalnya melalui kepala adat, karena delik yang tidak terdapat dalam KUHPidana ternyata di dalam hukum adat masuk golongan delik yang dianggap berat atau perbuatan yang menentang keselamatan masyarakat seluruhnya. Contoh delik yang dianggap berat adalah incest (masih dipertahankan pada masyarakat adat Bugis, Makasar dan Bali). Jika diperhatikan memang perbuatan tersebut sangat bertentangan dengan kepribadian bangsa Indonesia (yang menjunjung tinggi norma kesusilaan). Tetapi ada juga hukum adat yang bertentangan dengan HAM sehingga harus dihapuskan pemberlakuannya. Misalnya pemenggalan kepala manusia hanya untuk mahar perkawinan atau pembunuhan untuk dijadikan persembahan dalam suatu ritual. Dengan demikian diharapkan timbul keselarasan dan keseimbangan dengan mengindahkan norma-norma secara musyawarah mufakat agar tercapai kepastian hukum.

\section{REFERENSI}

OK. Khairuddin, Sosiologi Hukum, Sinar Grafika, Jakarta.

Prof. Dr. R. Soepomo, SH, Bab-Bab tentang Hukum Adat, Balai Pustaka, Jakarta, 2013

Prof. Dr. C. Dewi Wulansari, SH, MH, SE, MM., Hukum Adat Indonesia Suatu Pengantar, Refika Aditama, Bandung, 2016

Rianto Adi, Sosiologi Hukum Kajian Hukum secara Sosiologis, Yayasan Pustaka Obor Indonesia, Jakarta.

Satjipto Rahardjo, Sosiologi Hukum Perkembangan Metode dan Pilihan Masalah, Genta Publishing, Yogyakarta.

Satjipto Rahardjo, Ilmu Hukum, P.T. Citra Aditya Bakti, Bandung.

Soleman B. Taneko, Pokok-pokok Studi Hukum dalam Masyarakat, PT. Raja Grafindo Persada, Jakarta.

Soerjono Soekanto, Hukum Adat Indonesia, PT. Raja Grafindo Persada, Jakarta, 2016 